\title{
Organizational Dysfunctions: Sources and Areas
}

\author{
Jacek Pasieczny, Beata Glinka
}

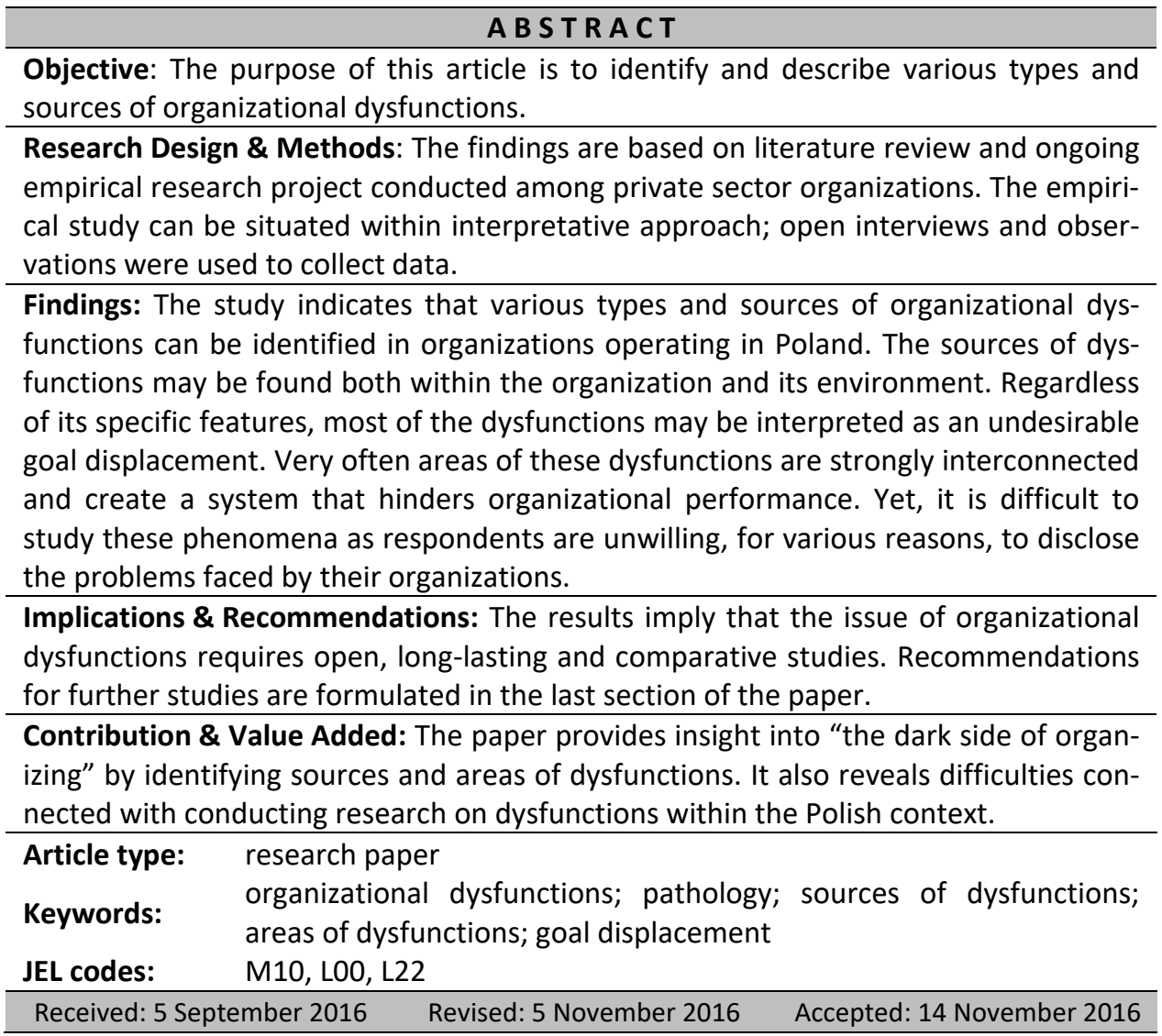

\section{Suggested citation:}

Pasieczny, J., \& Glinka, B. (2016). Organizational Dysfunctions: Sources and Areas. Entrepreneurial Business and Economics Review, 4(4), 213-223, DOI: http://dx.doi.org/10.15678/EBER.2016.040413 


\section{INTRODUCTION}

The phenomena and mechanisms as a result of which organizations fail to reach their goals are commonly referred to, among others, as errors, dysfunctions, pathologies, or deficiencies. However, the analysis of these phenomena requires a more precise definition. Error means doing something incorrectly, it is inaccuracy or a phenomenon as a result of which the system fails to work as intended. Error is generally of an occasional character (Pasieczny, 2013, p. 378). Although organizational consequences of errors can be quite severe, their perpetrators do not always bear the consequences. It is (usually) connected with the lack of intentionality. An error is treated as an unintentional deviation, occurring against the will of its perpetrator. Interestingly enough, the intended action with the same adverse effects usually faces general disapproval and brings organizational consequences. On the other hand, some researchers imply, that errors and failures, even if non-intentional are often treated as blameworthy (Edmondson, 2011). That can start a blame game and prevent learning from failures. This suggests that even economic institutions use non-economic criteria for evaluating phenomena and behaviour.

Before we move on with our analysis, the concepts that we discuss in our paper need to be clarified. Dysfunction is a phenomenon that adversely affects a particular social system. Prolonged exposure to dysfunction can lead to a pathological condition. To put it simply, dysfunction can be treated as a mechanism hindering smooth operation of an organization. Pathology in organization is a relatively permanent deficiency, which causes waste in the economic sense and (or) in the moral sense surpassing the limits of social tolerance (Kieżun, 2012, p. 16). Similarly, pathology in management is a serious long-term deficiency in the processes of the organization's management. However, the boundary between dysfunction and pathology is sometimes difficult to grasp, as indicated in the literature. For example, according to Stocky "pathology is any dysfunction in the organization; one that prevents the organization from achieving its realistic targets in due time and with the use of specific measures" (Stocki, 2005, p. 49). Organizational deficiency is a term of a praxeological origin and is the opposite of efficiency - praxeological evaluation of good performance in terms of effectiveness, benefits and economy. Deficiency is therefore insufficient extent of efficiency in an organization or in a specific process.

The purpose of our text is to describe various types and sources of organizational dysfunctions. In order to do so we analyse the relevant literature and conduct empirical qualitative research. In the subsequent parts of this article we present a short literature review, describe methods used in empirical study and present initial results of our empirical investigation, including both sources and areas of pathologies. Conclusions, as well as some limitations and suggestions for further research are included in the last part of the paper.

\section{LITERATURE REVIEW}

\section{Dysfunctions as a Field of Analysis}

Dysfunctions have been analysed and studied since the very beginning of their existence. These issues (though not explicitly) are discussed in works by Xenophon or in the Code of 
Hammurabi. The whole industrial trend of classical management science derived from the desire to eliminate organizational dysfunctions by engineers. Yet, contemporary literature addresses the problem surprisingly rarely, given the scale of the needs. Many studies are fragmentary or have informative character only. Perhaps positive developments seem more attractive as an object of the analysis than negative ones, as success is more appealing to researchers than failure (Samuel, 2010, p. 1).

Only a few researchers have made dysfunction the central point of their analyses. Most address the issue merely "by the way", analysing selected aspects of organizational management. These authors include, among others Einarsen, Hoel, Zapf and Cooper (2005), Goffnett, Lepisto and Hayes (2016), Jamil and Panday (2012), and others.

Researchers focusing on administration were more successful. Crozier (1967), Merton (1940; 1957), Selznick (1943), Gouldner (1954), Finer (1941), Osborne and Gaebler (1992), Weingast and Moran (1983), Kieżun (2012), or Batko (2013), and many others managed to identify the sources, mechanisms and describe dysfunctions in the functioning of bureaucratic organizations.

Analysis of dysfunction in business is - as already noted - difficult and very often limited to selected areas (hierarchical problematic, functional areas) of the organization. This does not mean, however, that no attempts have been made to develop broader and more universal theories. Some of them combined business and public administration in their works. The authors of such theories include Barnard (1940), March and Simon (1964), Kieżun (2012), Stocki (2005), Koźmiński (2004; 2008), Glinka and Pasieczny (2008), Argyris (1977; 1999), Samuel (2010), Meyer and Zucker (1989), Guy (1989), and others. It must be noted that a broad spectrum of problems has been taken under consideration: the nature of managerial work, organizational structures, goals formulating and many others.

The variety of concepts addressing dysfunctions illustrates the practical and theoretical importance of this phenomenon. The field is developing, and the changing business environment calls for more research and deeper understanding of the nature, sources and consequences of dysfunctions.

\section{Sources of Organizational Dysfunctions and Pathologies}

Pathologies understood as long-term deficiencies in operations, are inherent in all forms of organized human activity. It may be even concluded that management would not have become a separate discipline if people had not faced problems with the organization (in a substantive sense, attribute sense and functional one). Assessment of a phenomena and identification of sources of pathologies have always been subject to constant evolution. This is due to the aforementioned multiplicity and dynamics of stakeholders, but also changes in the area of moral standards. The analysis of pathologies is indeed firmly rooted in the ethical context.

The mechanism of negative empowerment (autonomy) leading to goal displacement can be considered as an universal source of pathologies. Negative empowerment involves putting, among others, the ultimate goal aside or replacing it with another main goal, changing the mode of operation; it is a change of the goal in which the mean (intermediate target) becomes the main objective (Kieżun, 2012, p. 16). Negative empowerment (autonomy) and goal displacement are the main sources of bureaucracy, addressed, among others by, March and Simon (1964), Merton (1957) or Crozier (1964). 
Goal displacement mechanisms (although the author himself does not use this concept) are the basis of analysis by Dobrzyński (2012), who studies pathologies in the functioning of modern corporations. Most authors, however, are looking for sources of pathologies in selected areas of the organization's operation, or focus their attention on selected organizations. Sources of pathologies in administrative organizations are easy to identify because they are inherent in the assumptions of the bureaucratic model - application of the principles of formalization, impersonality, documentation and area of competences strictly defined by the law results in a negative internalization of organizational rules, errors in formalization and behaviour oriented on risk minimization by workers.

The study of the sources of pathologies in business is more difficult not only because of difficult access to data, but also due to a different nature of business organizations. Unlike administration, their operation is based - or is supposed to be based - on the universal homeostasis market mechanism, which stimulates them to undertake ongoing corrective measures. Prolonged pathological conditions in organizations operating on the market can be deadly threats for them. Therefore, abnormalities in market organizations are rapidly corrected, and thus more difficult to observe. For this reason, people usually do not look for general mechanisms of pathology in companies, but for sources of selected subsystems of organizational pathologies. In other words: we expect organizations (understood as certain socio-technical systems operating within their environment) to correct dysfunctions in order to regain equilibrium (Koźmiński \& Obłój, 1989). Moreover, managers have many different tools to help them overcome the lack of equilibrium: strategy, structure, culture, procedures (Koźmiński \& Obłój, 1989). However, in contrary to this typical approach Meyer and Zucker (1989) present the concept of permanently failing organizations - organizations that are permanently unable to obtain their goals and correct major dysfunctions. In other words, under some circumstances homeostasis cannot be taken for granted, and that calls for a deeper reflection on pathologies in business organizations.

The causes of pathological phenomena in the broadly understood social domain, are observed, among others, by Stocki (2013), Lencioni (2005) or Samuel (2010). Pathologies are the result of organizations taking over the behaviour and the system of values of their chief members. They include in particular, the reluctance to change or immunization to change, loss of responsibility and commitment, lack of trust, fear of conflict, dishonesty, greed, and other features.

Other researchers look for sources of pathologies in philosophy, politics and specific organizational solutions (Gestmann, 2001; Slatter \& Lovett, 2001). Pathogenic organizational solutions include, among others, poorly designed and excessively oppressive control systems, hiding and shifting costs to other parts of the organization (budgets), dogmatism, functional "shredding" (fragmentation) of organization, lack of redundancy, inefficient communication systems and many other problems.

Phenomena occurring at the boundary of the organization and its environment may be treated as a separate category of sources of pathologies. This area is addressed, among others, by Koźmiński (2008), Samuel (2010), Meyer and Zucker (1989), Bogle (2009). They include such potentially dangerous phenomena as strong pressure to do things quickly, shorter planning horizon, pathological lack of confidence, focus on con- 
tinuous growth of profits, clientelism and blurring boundaries between politics and business, and other problems.

\section{MATERIAL AND METHODS}

The research project underlying this article is based on interpretative assumptions. This projects consists of two major parts: literature review and empirical study conducted ${ }^{1}$ in Polish private owned organizations of different sizes. The study continues, yet the already carried out work allows us to draw preliminary conclusions.

The first stage of the study was to analyse the literature. This helped to identify a "working list of dysfunctions" which was intended to further the studies. The second stage of the study was designed to broaden this "working list of dysfunctions", as well as to understand their nature and sources. For that reason qualitative methods were used to obtain data: anthropological interviews (with an open list of topics to be discussed with interviewees) and observations. This is an ongoing project, over 20 interviews were conducted till now (March 2015 - September 2016). The interviews were conducted with managers at various management levels, and entrepreneurs/business owners. All, except one, managed organizations or business units in Poland. One of the respondents was a high-level manager of an international company, first in Romania and later in Russia. The length of the interviews ranged from 30 minutes (the shortest interview) to over 6 hours (the longest, continued at several meetings). Among the respondents, there were 8 entrepreneurs (owners of small or micro businesses), 13 managers of mediumsized and large companies and one employee of a housing co-operative. Most of the interviews were recorded and transcribed, during the rest detailed notes were made. Transcribed text as well as research notes were the basis of analysis and identification of categories.

In the empirical study some serious difficulties were encountered. They included, firstly, difficulties in obtaining information, and secondly - interpretation problems. Problems with obtaining information are universal and they are widespread. However, in the case of studies on dysfunction, the reluctance to participate in the study seems to be even more visible. Respondents refuse to participate in the study or agree to be interviewed provided none of the raised problems may be subject of any publication, even anonymous one. Some interviewees do not allow for any recording. Such reactions, though understandable, make researchers' work very difficult. Organizations care about their image and employees are worried about their jobs. During the research, the authors of the article encountered situations where employees were reluctant to even provide information, which was available on the organizations' websites.

Problems with interpretation stem from the fact that many organizational issues cannot be unambiguously assessed. Different, and sometimes even the same groups of stakeholders, yet playing different roles in different circumstances, provide different interpretations to the observed phenomena. This means in practice that a specific issue may be viewed differently by different actors in an organization - executives, subordinates, trade unions, etc. Moreover, in a private conversation various phenomena can be presented and assessed in quite a different way than during official speeches, in the

\footnotetext{
${ }^{1}$ Currently the team of 3 researchers is involved in interviews' conducting.
} 
presence of others etc. The problem is also human tendency to look for the closest, direct causes of the problem only. Senge (2002, pp. 33-34) refers to it as the "focus on events". This constitutes an obstacle, especially when searching and analysing organizational dysfunctions, namely mechanisms distorting smooth operation of the organization.

The above-mentioned issues as well as the objective of the study, namely to get to know, understand and create a "non-exhaustive list of dysfunctions" were a factor determining the choice of the methodology for the second stage of the study. It would be difficult or even impossible to achieve a similar objective with the use of quantitative methods.

\section{RESULTS AND DISCUSSION}

\section{Sources of Dysfunction}

In the literature review section of our paper we described three major groups of sources of dysfunctions discussed in the literature: (i) social domain/system, (ii) internal solutions (systems, procedures, management philosophy), (iii) environment/management at the boundaries.

\section{Social Domain}

Our research, in general, supports the assumption of an importance of a social system as a potential source of dysfunctions. These problems were pointed by the interviewed senior managers, who indicated dishonesty and lack of loyalty among employees as sources of pathologies. Medium level managers also pointed to bad relationships, which are the result of abuse of or improper use of power by superiors.

Entrepreneurs paid the least attention to social sources of pathologies. Only a few of them mentioned the problem of dishonesty, but - interestingly - attributed it to the conditions of cooperation with large international corporations. In their view, there is a serious contradiction between the declarative domain (to which they include, among others, the existing codes of business ethics in corporations) and unfair practice used in cooperation between large enterprises with small companies.

\section{Internal Solutions}

One of the surprising results of our study was that managers and entrepreneurs rarely considered internal solutions as a source of pathologies. In the conducted studies, only few respondents - managers in corporations - considered some of the above-mentioned phenomena to be a source of dysfunction. Several respondents addressed the issue of excessive economization in the organizations' operations which results in different pathologies. For obvious reasons, these phenomena were significantly less apparent for entrepreneurs - owners of small businesses.

This result can be interpreted in many ways. Firstly, the simple interpretation is that in practice internal solutions - structures, policies etc. - are not significant as a source of dysfunctions. Secondly, managers and entrepreneurs can avoid this area, as, at least to some extent, it is under their control (i.e they may avoid admitting own mistakes). This area requires further empirical evidence. 


\section{Environment/Boundaries}

In our study, respondents often pointed to this group of sources of pathologies. The state was usually considered to be the most powerful stakeholder. Businesses almost unanimously referred to the state as a dangerous and unfriendly institution. The state is perceived by them as a uniform entity generating external burdens and uncertainty. This negative perspective is not even changed by reliefs and incentives offered to businesses by the state. The state is assessed as a dysfunctional entity and an entity generating dysfunctions. Managers also mentioned the state as a source of pathologies, but also pointed to the very strong dysfunctional influence of the media, cultural conflicts and structures of the business environment.

\section{Areas of Dysfunction}

Pathologies are manifested in various ways and in different areas of the organization. Depending on the assumptions they may be analysed in the context of the theory of the population ecology of organization, life cycle of the organization, psychopathology or by using the metaphor of the body system. Also achievements of the followers of the diagnostic approach, seeking and creating instruments of identification and analysis of pathologies in specific situational conditions are quite abundant. This group includes such authors as Stocki (2013), Gestmann (2001), Guy (1989), and Bennett and Robinson (2000), who created an interesting typology of organizational behaviour deviating from the standard.

On the basis of the conducted interviews we can identify two major areas of pathologies: a) strategic area and b) operational area. Although such a division is not always clear-cut, yet it helps to organize diversified problems and issues which were revealed during the interviews in a spontaneous and - consequently - often a bit chaotic manner.

\section{Strategic Area}

The main pathologies identified during the research in the strategic area are:

1. Lack of a clear strategic objective. Respondents pointed to the lack of clearly formulated organizational goals, constantly changing goals and inconsistencies in their implementation, either partial or total failure to translate strategic goals into operational activities. Interestingly, this problem was also mentioned by entrepreneurs, who often were not able themselves to determine their strategic objectives and perceived the risks resulting from this fact.

2. Absence of relationship between the inputs and the effects. This phenomenon is observed in larger companies mainly, where cost centres are organizationally separated from income centres. This can be manifested by investments in low profitability projects, elimination of key resources, or dysfunctional organizational suboptimizations.

3. Organizational dissociation - a type of disorder of organizational identity manifested in growing autonomy of divisions/departments or internal contradictions. This can be manifested in excessive economization (savings) accompanied by wastefulness in the organization itself. 
4. Lack of trust. This seems to be a universal pathology which is present in both large corporations and small businesses. Apart from the sources of this pathology (they are largely external), it results in numerous problems, such as bad relations within the organization, excessively complex control systems, poor relations with external stakeholders etc. As a result, all this boosts transaction costs.

5. Exhaustion of resources. Exhaustion of resources is the most often an undesirable consequence of decisions, and not the result of the deliberately implemented policy. Nevertheless, the consequences of this pathology can be of strategic importance for the organization. In practice, exhaustion of resources can lead to excessive outsourcing, staff overloading with duties, layoffs (or employee departure caused, for example, underestimation) of experienced employees etc. In the case of small businesses this can be a physical overloading of the owner with responsibilities or the failure to ensure effective funding for the company's growth.

\section{Operational Area}

In the area of operational subjects, the respondents mentioned numerous phenomena which could be classified as pathologies. The most important of these include:

1. Pathological organizational games. This problem was pointed out by managers of larger companies. Games aimed at gaining control over scarce organizational resources are manifested in the formation of strong informal groups, "empire building" by growing number of organizational units, reluctance to share knowledge or only superficial activity.

2. Bad relationships. This phenomenon, depending on its intensity, may be either a factor slightly impeding work or a serious pathology threatening the functioning of the company. Bad relationships may prevail between superiors and subordinates, but can also concern horizontal relationships. Symptoms of bad relationships include a range of behaviours, from gossiping and backbiting to violence and jeopardizing.

3. Ineffective communication. Despite unlimited technical possibilities of information flows, there are problems with communication in many organizations. The main obstacle is not the technical aspect, but the lack of knowledge or lack of motivation of executives to communicate effectively. Inadequate communication often results in misunderstandings within the organization and in inferior contacts between the organization and its environment, low motivation, conflicts and problems with the introduction of changes.

4. Inappropriate division of labour. Many authors emphasize negative consequences of excessive formalization. Meanwhile, our respondents mentioned insufficient formalization in the area of the division of labour as a very tedious phenomenon. It occurs that higher level superiors are reluctant to make precise division of duties among employees. They tend to officially motivate it by the desire to ensure flexibility of the organization, but in practice it can also be perceived as part of organizational game, aimed at safeguarding the interests of the stronger party in a superior-subordinate relationship. This phenomenon may result in conflicts, declining motivation or quality problems.

5. Unethical behaviour and breach of the law. This problem can affect all levels and all organizations and it is the consequence of organizational policies to a limited extent 
only. Corruption, bribery, theft, mobbing, sexual harassment can occur also in those organizations which put an emphasis on ethical behaviour. Sometimes, however, such actions and attitudes are somewhat forced by external conditions (e.g. the necessity to submit dumping bids in public tenders) or are the result of low moral standards in the organization. The respondents noted a number of unethical and illegal forms of behaviour, but usually outside their organization.

\section{CONCLUSIONS}

Pathologies are an integral part of the organization and the first theoretical studies in the field of management focused on dysfunctions and pathologies. Despite many studies, it is still a relatively underresearched area. This is due both to the difficulty in obtaining information, and the specific character of the topic itself characterized by ambiguity, subjectivity and dynamics. Pathologies can be observed in all subsystems of the organization and its environment. Their identification is difficult, but possible and desirable. Although the Western business culture is a culture of achievement and success, yet identification of the causes, mechanisms and symptoms of pathological phenomena can bring important theoretical and - above all - practical benefits.

Our study revealed some similarities with other researchers' findings, especially in the field of external sources of pathologies (Stocki, 2013; Samuel, 2010). Some unexpected areas and sources of pathologies were also revealed in our research. For example, insufficient formalization, described as a potential source of pathologies can be a surprising declaration in the times of fighting with bureaucracy in both public and private sector, and constant creativity quests considered as a source of competitive advantages. Also, one of the surprising results of our study was that managers and entrepreneurs rarely considered internal solutions as a source of pathologies. From the psychological point of view this phenomenon is quite easy to understand. However it indicates, that in most cases, an open culture in which managers and other employees are willing to reveal mistakes and learn from them is still not a reality. Such a culture may be declared by managers, but its implementation requires more time, effort, and reflective approach.

At this point two main limitations must be stressed: the number of interviews conducted and the nature of the phenomenon under investigation. As far as the first limitation is considered, we plan to continue the research project to collect more data and obtain theoretical saturation. The second limitation cannot be fully addressed, but in order to decrease its impact on the research results, we decided to apply qualitative methods, and in the future we plan to include more diversified methods of data collection (more observations, projection, narrative methods). More long-term, comparative studies are needed to provide a better understanding of the phenomenon under investigation, especially in a private sector. As we mentioned, more theories were formulated to address the issues of pathologies and dysfunctions within a public administration.

It seems, that the following areas of comparison may be crucial for a deeper understanding of the phenomenon of dysfunction and its causes:

- public vs private sector organizations,

- organizations operating in different business contexts (economic, legal, cultural). 
On the base of such comparative in-depth studies not only more general conclusions will be possible, but also the formulation of practical guidelines for manager on how to avoid dysfunctions.

\section{REFERENCES}

Argyris, C. (1977). Double Loop Learning in Organizations. Harvard Business Review, 55(5), 115-125.

Argyris, C. (1999). On Organizational Learning, 2nd ed. Malden, Mass.: Blackwell Business.

Barnard, C.I. (1940). The Functions of the Executive. Cambridge: Cambridge University Press.

Batko, R. (2013). Golem, Awatar, Midas, Złoty Cielec. Organizacja publiczna w płynnej nowoczesności. Warszawa: Sedno.

Benett, R., \& Robinson, S. (2000). Development of a Measure of Workplace Deviance. Journal of Applied Psychology, 85(3), 349-360.

Bogle, J.C. (2009). Dość. Warsaw: PTE.

Crozier, M. (1964). The Bureaucratic Phenomenon. London: Tavistock.

Crozier, M. (1967). Biurokracja. Anatomia zjawiska. (The Beaurocractic Phenomenon). Warsaw: PWE.

Dobrzyński, M. (2012). Doktryna szoku jako inspiracja współczesnego zarzq̨dzania. Warsaw: Wydawnictwo Wydziału Zarządzania UW.

Edmondson, A. (2011). Strategies for learning from failure. Harvard Business Review, 4, 48-55.

Einarsen, S., Hoel, H., Zapf, D., \& Cooper, C.L. (2005). Workplace bullying: Individual pathology or organizational culture? In V. Bowie, B. Fisher \& C.L. Cooper (Eds.), Workplace Violence: Issues, Trends, Strategies. London: Willan.

Finer, H. (1941). Administrative Responsibility in Democratic Government. Public Administration Review, 1(4), 335-350.

Gestmann, M. (2001). Sabotaż w miejscu pracy. Cracow: Wydawnictwo Profesjonalnej Szkoły Biznesu.

Glinka, B., \& Pasieczny, J. (2008). Błędy menedżerskie: wybrane źródła i implikacje dla rozwoju organizacji. Problemy Zarzq̨dzania, 4, 151-168.

Goffnett, S.P., Lepisto, L., \& Hayes, R. (2016). Using the socio-economic approach to management to augment Lean Six Sigma. International Journal of Productivity and Performance Management, 65(1), 80-97.

Gouldner, A.W. (1954). Patterns of Industrial Bureaucracy. Glencoe: Free Press.

Guy, M. (1989). From Organizational Decline to Organizational Renewal: the Phoenix Syndrome. New York: Quorum Books.

Jamil, I., \& Panday, P. (2012). Inter-Organizational Coordination and Corruption in Urban Policy Implementation in Bangladesh: A Case of Rajshahi City Corporation. International Journal of Public Administration, 35(5), 352-366.

Kieżun, W. (2012). Patologia transformacji. Warszawa: Poltext.

Koźmiński, A.K. (2004). Zarzq̨dzanie w warunkach niepewności. Warsaw: Wydawnictwo Naukowe PWN.

Koźmiński, A.K. (2008). Koniec świata menedżerów. Warsaw: Wydawnictwa Akademickie i Profesjonalne. 
Koźmiński, A.K., \& Obłój, K. (1989). Zarys teorii równowagi organizacyjnej. Warsaw: PWE.

Lencioni, P. (2005). Pięć dysfunkcji pracy zespołowej. Konstancin-Jeziorna: MTBiznes.

March, J., \& Simon, H. (1964). Teoria organizacji (Organization Theory). Warsaw: PWN.

Merton, R.K. (1940). Bureaucratic Structure and Personality. Social Forces, 18(4), 560-568.

Merton, R.K. (1957). Social Theory and Social Structure. New York: Free Press.

Meyer, M.W., \& Zucker, L.G. (1989). Permanently Failing Organization. Newbury Park: SAGE Publications.

Osborne, D., \& Gaebler, T. (1992). Reinventing Government: How the Entrepreneurial Spirit Is Transforming the Public Sector. Reading, MA: Addison-Wesley.

Pasieczny, J. (2013). Patologie w zarządzaniu (Pathologies in management). In J. Bogdanienko \& W. Piotrowski (Eds.), Zarzqdzanie. Tradycja i nowoczesność. Warsaw: PWE.

Samuel, Y. (2010). Organizational Pathology. Life and Death of Organizations. New Brunswick Transaction Publishers.

Selznick, P. (1943). An Approach to a Theory of Bureaucracy. American Sociological Review, 8(1), 47-54.

Senge, P. (2002). Piqta dyscyplina. Teoria i praktyka organizacji uczqcych się. (The Fifth Discipline: The Art and Practice of the Learning Organization). Cracow: Oficyna Ekonomiczna.

Slatter, S., \& Lovett, D. (2001). Restrukturyzacja firmy. Warsaw: WIG-Press.

Stocki, R. (2005). Patologie organizacyjne - diagnoza i interwencje (Organizational pathologies diagnosis and interventions). Cracow: Oficyna Ekonomiczna.

Stocki, R. (2013). Diagnoza organizacji od A do Z. Warsaw: Wolters Kluwer.

Weingast, B., \& Moran, M. (1983). Bureaucratic Discretion or Congressional Control? Regulatory Policymaking by the Federal Trade Commission. Journal of Political Economy, 91(5), 765-800.

\section{Authors}

The contribution share of authors is equal and amounted to $50 \%$ each of them.

\section{Jacek Pasieczny}

Associate Professor in the Department of Entrepreneurship and Management Systems of the Faculty of Management, University of Warsaw.

Correspondence to: Dr hab. Jacek Pasieczny; University of Warsaw, Faculty of Management; 02-678 Warszawa, ul. Szturmowa 1/3, Poland; e-mail: jpasieczny@wz.uw.edu.pl

\section{Beata Glinka}

Professor, the head of the Department of Entrepreneurship and Management Systems of the Faculty of Management, University of Warsaw.

Correspondence to: Prof. dr. hab. Beata Glinka; University of Warsaw, Faculty of Management; 02-678 Warszawa, ul. Szturmowa 1/3, Poland; e-mail: b.glinka@uw.edu.pl

\section{Copyright and License}

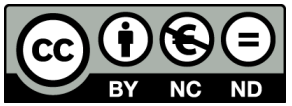

This article is published under the terms of the Creative Commons Attribution - NonCommercial - NoDerivs (CC BY-NC-ND 3.0) License http://creativecommons.org/licenses/by-nc-nd/3.0/ 
